\title{
EKONOMI ISLAM DAN KEARIFAN LOKAL
}

\author{
Rahmani Timorita Yulianti \\ FIAI Universitas Islam Indonesia Yogyakarta \\ Email: rahmani_ty@yahoo.com
}

\section{Abstract}

Indonesia is an archipelago which has a diverse system of cultural customs of the archipelago. With so much local wisdom in it. Related to the system and the economic behavior of the Indonesian people, whether in the traditional system of culture of the archipelago there is an economic system that is still practiced by the community? What is the economic system there are indigenous cultures of the archipelago is relevant to the economic principles of Islam? Therefore, space exploration and assessment of local knowledge into separate claims for one of the methods of economic development of Islam in Indonesia. Responding to the scientific development of new discourse of Islamic economics, the paper seeks to discuss further on, (1) What are the sources of Islamic economic law that allows synergy between Islamic economics and local wisdom?, (2) How is the meeting point 'urf and local wisdom, and (3) How can tolerance towards indigenous Islamic economics?

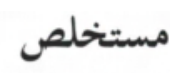

في دولة اندونسيا بحموعة الجزر و لما متعدد العادات الثقافية في كل جُزر. ففيها عدد الحكمة المحلية. هل يطبّق المحتمع نظامَ الاقتصادي في تلك العادة بوجود النظام و حال الاقتصاد بلمتمع الاندونسي؟ . هل ذالك يوافق بدليل إقتصاد الاسلام؟ لمذا، هناك بيئة الاكتشاف و بحث الحكمة المحليّة وهي تكون مطلبةً نفسيةً لاحد الطريقة في تنمية اقتصاد الإسلام في دولة اندونسيا. واستجابة الكلام في تنمية

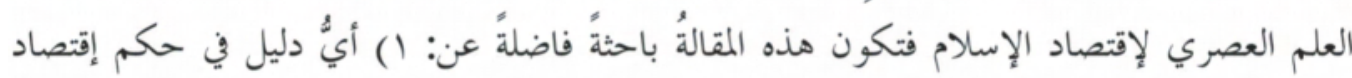

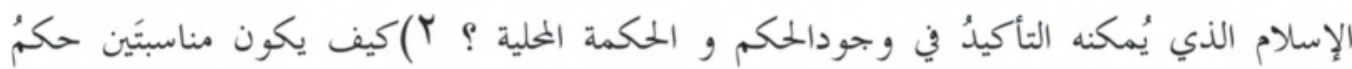

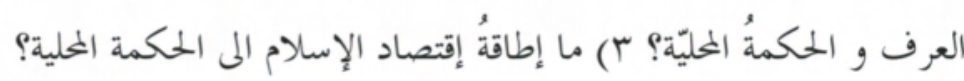

Keywords: Ekonomi Islam, 'Urf, Kearifan Lokal. 


\section{A. Pendahuluan}

Ekonomi Islam di Indonesia saat ini mengalami kemajuan yang sangat pesat dan berkesinambungan. Kemajuan tersebut meliputi berbagai dimensi seperti kajian akademis di Perguruan Tinggi maupun secara praktik operasioanl yang terjadi di lembaga- lembaga perekonomian Islam. ${ }^{1}$

Perkembangan tersebut diharapkan semakin melebar meliputi berbagai aspek, seperti kebijakan ekonomi negara, ekonomi pemerintah daerah, ekonomi makro (kebijakan fiskal, public finance, strategi mengatasi kemiskinan serta pengangguran, inflasi, kebijakan moneter), dan permasalahan ekonomi lainnya, seperti produksi, konsumsi, distribusi, sirkulasi, upah, Sumber Daya Manusia, Sumber Daya Alam, Industri, regulasi ekonomi, kesejahteraan dan sebagainya.

Dalam perkembangan di berbagai bidang tersebut, agar mampu bersaing dan sesuai dengan kebutuhan masyarakat, diperlukan regulasi yang memadai, inovasi produk, inovasi strategi pengembangan, inovasi strategi marketing serta merespon secara akomodatif bentuk-bentuk baru transaksi ekonomi, bisnis dan keuangan dan perbankan Islam dengan tetap mematuhi prinsip-prinsip syari'ah dalam operasionalnya.

Perkembangan tersebut diharapkan berimplikasi secara signifikan kepada banyaknya masyarakat Indonesia yang semakin tertarik beraktivitas ekonomi sesuai dengan prinsip-prinsip ekonomi Islam baik di perkotaan maupun di pedesaan.

Sehubungan dengan hal tersebut, secara geografis Indonesia adalah negara kepulauan yang memiliki beragam sistem adat kebudayaan nusantara. Terkait dengan sistem dan perilaku ekonomi masyarakat Indonesia, apakah dalam sistem adat kebudayaan nusantara terdapat sistem ekonomi yang masih dipraktikkan oleh masyarakat? Apakah sistem ekonomi adat kebudayaan nusantara tersebut ada yang relevan dengan prinsip-prinsip ekonomi Islam?

Oleh karena itu eksplorasi terhadap kekayaan luhur sistem ekonomi adat budaya bangsa tersebut, sangat perlu untuk dilakukan, sekaligus juga berupaya untuk mengkritisi eksistensinya terkait dengan keniscayaan adanya perubahan masyarakat dalam berperilaku ekonomi.

Sistem ekonomi adat budaya nusantara merupakan kearifan lokal yang menjadi salah satu asset bangsa Indonesia yang pluralistik. Ruang eksplorasi dan pengkajian

1 Seperti Perbankan Syariah, Asuransi Syariah, Pasar Modal Syariah, Reksadana Syariah, Obligasi Syariah, Leasing Syariah, Bank Pembiayaan Rakyat Syariah, Baitul Mal wat Tamwil, Koperasi Syariah, Pegadaian Syariah, Dana Pensiun Syariah, Lembaga Keuangan Publik Islam seperti Lembaga Pengelola Zakat Infaq Shadaqah dan Lembaga Pengelola Wakaf 
kearifan lokal menjadi tuntutan tersendiri bagi salah satu metode pengembangan ekonomi Islam di Indonesia.

Dalam wacana majalah Sharing ${ }^{2}$ dipaparkan bahwa, ekonomi Islam selama ini bisa dikatakan sudah menerapkan proses sinergi ilmu, yaitu dengan mensinergikan ajaran Islam dengan ilmu ekonomi. Namun setelah itu ilmu ekonomi Islam seperti mengalami stuck atau kebuntuan karena para ilmuwan dan praktisinya melulu berkutat pada hal-hal seperti riba, zakat, mudharabah dan sebagainya. Hampir tidak ada perspektif baru yang bisa dikatakan mencengangkan atau luarbiasa. Hal tersebut sudah lama dikhawatirkan oleh Umer Chapra (2000) di bagian penghujung bukunya yang berjudul The Future of Economics: an Islamic perspective.

Kegelisahan Umer Chapra tersebut sempat terjawab oleh pemikir ekonomi Islam lain, M.A Chowdhury. Ia mengembangkan pendekatan sinergi antara ekonomi Islam dan politik yang terangkum dalam beberapa bukunya seperti Money In Islam: A Study in Islamic Political Economy (1997); The Islamic World-System: A Study in Polity-Market Interaction (2004); serta The Universal Paradigm and The Islamic World System: Economy, Society, Ethics And Science (2007). ${ }^{3}$

Merespon wacana pengembangan keilmuan baru ekonomi Islam dalam majalah Sharing tersebut, maka terkait dengan ekonomi Islam dan kearifan lokal, memunculkan beberapa kegelisahan pemikiran penulis yang urgen untuk didiskusikan lebih lanjut. Identifikasi kegelisahan pemikiran tersebut adalah sebagai berikut: (1) Apa saja sumber hukum ekonomi Islam yang memungkinkan disinergikan antara ekonomi Islam dan kearifan lokal?, (2) Bagaimana titik temu 'urf dan kearifan lokal, dan (3) Bagaimana toleransi ekonomi Islam terhadap kearifan lokal?

\section{B. Sumber Hukum Ekonomi Islam}

Tidak ada perbedaan antara sumber hukum Islam secara umum dengan sumber hukum ekonomi Islam. Karena kajian ekonomi dalam Islam adalah bagian dari pembahasan tentang hukum Islam. Maka sumber hukumnyapun sama yaitu Al Qur'an, Sunnah, Ijma', Fatwa Sahabat Nabi, Qiyas, Istihsan, ’Urf, Mashalih Mursalah, Sadd adz-dzara'i, Istishhab dan Syar'u man qablana.

Dengan demikian setiap aktivitas ekonomi harus berlandaskan kepada sumbersumber hukum ekonomi Islam dan tidak boleh bertentangan dengan prinsip-prinsip ekonomi Islam dalam berijtihad atas suatu fenomena ekonomi. Dalam ekonomi

2 TON, Pengembangan Keilmuan Baru Ekonomi Islam, dalam Sharing, Majalah Ekonomi dan Bisnis Syariah, Edisi 43 Tahun IV Juli 2010, hal. 48.

Ibid. 
Islam, terdapat prinsip-prinsip yang harus dipenuhi apabila sebuah interaksi antar sesama manusia akan dilakukan. Prinsip-prinsip ini harus dijadikan sebagai aturan dalam melakukan aktivitas ekonomi.

Prinsip-prinsip ekonomi Islam tersebut yaitu (1) pada asalnya aktivitas ekonomi itu boleh dilakukan sampai ada dalil yang mengharamkannya, (2) aktivitas ekonomi tersebut hendaknya dilakukan dengan suka sama suka ('an taradhin), (3) kegiatan ekonomi yang dilakukan hendaknya mendatangkan maslahat dan menolak madharat (jalb almashalih wa dar'u al-mafasid), dan (4) dalam aktivitas ekonomi tersebut terlepas dari unsur gharar, riba, kedzaliman, dan unsur lain yang diharamkan berdasarkan syara'.

Dalam prinsip pertama mengandung arti, hukum dari semua aktivitas ekonomi pada awalnya diperbolehkan. Kebolehan itu berlangsung selama tidak atau belum ditemukan nash - Al-Qur'an dan Al-Hadis - yang menyatakan keharamannya. ${ }^{4}$ Ketika ditemukan sebuah nash yang menyatakan haram, maka pada saat itu pula akad mu'amalah tersebut menjadi terlarang berdasarkan syara'. Prinsip ekonomi Islam tersebut sebenarnya mengacu pada ketentuan umum yang termuat di dalam Al-Qur'an yang secara substansi berbicara tentang masalah ini, terdapat di dalam surat Al-Baqarah ayat 29 yang artinya: "Dialah Allah yang menjadikan segala yang ada di bumi untuk kamu."

Prinsip ekonomi Islam yang kedua adalah mu'amalah, hendaknya dilakukan dengan cara suka sama suka dan tidak ada unsur paksaan dari pihak manapun. Bila ada dalam sebuah aktivitas ekonomi ditemukan unsur paksaan (ikrah), maka aktivitas ekonomi tersebut menjadi batal berdasarkan syara'. ${ }^{5}$ Prinsip mu'amalah ini didasarkan pada nash yang tertuang dalam Al-Qur'an surat An-Nisa' ayat 29 yang artinya, "Hai orang-orang yang beriman, janganlah kamu saling memakan harta sesamamu dengan jalan yang batil, kecuali dengan jalan perniagaan yang berlaku dengan suka sama suka di antara kamu."

Sedangkan prinsip yang ketiga adalah mendatangkan maslahat dan menolak madharat bagi kehidupan manusia. ${ }^{6}$ Prinsip ini mengandung arti, aktivitas ekonomi yang dilakukan tersebut hendaknya memperhatikan aspek kemaslahatan dan kemadharatan. Oleh karena itu, aktivitas ekonomi yang dilakukan, hendaknya merealisasikan tujuan-tujuan syari’at Islam (maqashid al-syari ah), yakni mewujudkan

4 Prinsip ini diambil dari kaidah fikih " Hukum asal dalam semua bentuk mu'amalah adalah boleh dilakukan kecuali ada dalil yang mengharamkannya”, lihat H.A.Djazuli, Kaidahkaidah Fikih, 2006, Cetakan ke-1, Jakarta: Kencana Prenada Media Group, hal. 130.

5 Prinsip ini diambil dari kaidah fikih " Hukum asal dalam transaksi adalah keridhaan kedua belah pihak yang berakad, hasilnya adalah berlaku sahnya yang diakadkan”, lihat Ahmad alNadwi, al-Qawa’id al-Fiqhiyah, 1998,Cetakan ke-V, Beirut: Dar al-Qalam, hal. 95. 
kemaslahatan bagi manusia. Bila ternyata aktivitas ekonomi tersebut dapat mendatangkan maslahat bagi kehidupan manusia, maka pada saat itu hukumnya boleh dilanjutkan, bahkan harus dilaksanakan. Namun bila mendatangkan madharat, maka pada saat itu pula harus dihentikan.

Prinsip ketiga tersebut secara umum didasarkan pada firman Allah dalam surat Al-Anbiya ayat 107 yang artinya "Dan tidaklah Kami mengutus kamu melainkan untuk (menjadi) rahmat bagi seluruh alam.” Rahmat dalam ayat ini bisa diartikan dengan menarik manfaat dan menolak madharat (jalb al-manfa'ah wa daf al-madharah). Makna ini secara substansial seiring dengan yang ditunjukkan Al-Qur'an surat AlBaqarah ayat 185 yang menyatakan "Allah tidak menghendaki adanya kesempitan dan kesulitan (musyaqah)" dan surat An-Nisa' ayat 28 yang artinya "Allah menghendaki supaya meringankan bagimu, karena manusia itu diciptakan dalam keadaan lemah.”

Sedangkan prinsip terakhir, aktivitas ekonomi harus terhindar dari unsur gharar, riba, dzhulm, dan unsur lain yang diharamkan berdasarkan syara'. Syariat Islam membolehkan setiap aktivitas ekonomi di antara sesama manusia yang dilakukan atas dasar menegakkan kebenaran, keadilan, menegakkan kemaslahatan manusia pada ketentuan yang dibolehkan Allah SWT. Sehubungan dengan itu, syariat Islam mengharamkan setiap aktivitas ekonomi yang bercampur dengan kedzaliman, penipuan, muslihat, ketidakjelasan, dan hal-hal lain yang diharamkan dan dilarang Allah SWT.

Gharar $r^{7}$ mengacu pada sejumlah transaksi yang bercirikan ketidakpartian dan ketidakjelasan pada awal kontrak, yang diduga dapat meniadakan kerelaan dan juga merupakan bagian dari memakan harta manusia dengan cara yang batil. Jualbeli gharar adalah jual-beli yang mengandung unsur ketidaktahuan (jahalah) yang dapat membawa pada perselisihan, serta menyebabkan kemadharatan dan meniadakan kemaslahatan manusia.

Adapun riba adalah suatu tambahan atas pokok harta atau penggandaan yang berlebihan. ${ }^{8}$ Terdapat beberapa sebab atas pengharaman riba (1) karena Allah SWT dalam Al-Qur'an dan Rasulullah SAW dalam Al-Hadis jelas-jelas menyatakan riba diharamkan, (2) karena esensi riba' adalah perilaku orang untuk mengambil harta milik orang lain dengan tidak seimbang, (3) bisa menyebabkan orang malas untuk berusaha,

6 Prinsip ini diambil dari kaidah fikih " Menolak mafsadah didahulukan daripada meraih maslahat”, lihat H.A.Djazuli, Kaidah-kaidah Fikih, 2006, Cetakan ke-1, Jakarta: Kencana Prenada Media Group, hal. 11.

Abdul Azis Dahlan, 1996, Ensiklopedi Hukum Islam, Jakarta: PT. Ichtiar Baru Van Hoeve, hal. 1497. Frank E.Vogel dan Samuel L. Hayes, III, 2007, Hukum Keuangan Islam, Cetakan ke-1, Bandung: Penerbit Nusamedia, hal. 110 
karena selalu mengharapkan keuntungan dengan tanpa usaha yang riil, (4) karena dengan adanya riba' bisa menyebabkan hilangnya berbuat baik terhadap sesama manusia. ${ }^{9}$

Sedangkan aktivitas ekonomi yang mengandung unsur zhulm (kedzaliman) adalah aktivitas ekonomi yang bila dilakukan dapat merugikan pihak lain, seperti menumpuk-numpuk harta (ihtikar) yang dapat mengganggu mekanisme pasar. Dari uraian tersebut dapat dipahami, aktivitas ekonomi baru dianggap shahih apabila memenuhi prinsip-prinsip ekonomi Islam tersebut.

\section{C. 'Urf Dan Kearifan Lokal}

Di antara sumber-sumber hukum ekonomi Islam seperti Al Qur'an, Sunnah, Ijma', Fatwa Sahabat Nabi, Qiyas, Istihsan, 'Urf, Mashalih Mursalah, Sadd adzdzara', Istishhab dan Syar'u man qablana, maka 'Urf adalah sumber hukum ekonomi Islam yang dapat dijadikan sebagai dasar untuk mencari titik temu antara aktivitas ekonomi yang merupakan kearifan lokal dengan ekonomi Islam. Dengan demikian dapat dijustifikasi, apakah kearifan lokal bidang ekonomi tersebut relevan dengan hukum dan prinsip-prinsip ekonomi Islam.

Istilah kearifan lokal (local wisdom) mempunyai arti yang sangat mendalam dan menjadi suatu kosa kata yang sedang familiar akhir-akhir ini. Dalam pengertian kamus, kearifan lokal (local wisdom) terdiri dari dua kata yaitu kearifan (wisdom) dan lokal (local). Dalam Kamus Inggris Indonesia I. Markus Willy P.S.Pd, M.Dikkie Darsyah S.Pd dan Mieke $\mathrm{Ch}^{10}$, local berarti setempat, sedangkan wisdom (kearifan) sama dengan kebijaksanaan. Secara umum maka local wisdom (kearifan setempat atau kearifan lokal) dapat dipahami sebagai, gagasan-gagasan setempat (local) yang bersifat bijaksana, penuh kearifan, bernilai baik, yang tertanam dan diikuti oleh anggota masyarakatnya. ${ }^{11}$

Pengertian lain yang lebih terperinci tentang kearifan lokal adalah, kebenaran yang telah mentradisi atau ajeg dalam suatu daerah. Kearifan lokal merupakan perpaduan antara nilai-nilai suci firman Tuhan dan berbagai nilai yang ada. Kearifan lokal terbentuk sebagai keunggulan budaya masyarakat setempat maupun kondisi geografis dalam arti luas. Kearifan lokal merupakan produk budaya masa lalu yang

8 Ibid., hal. 93.

9 QS. Ar Ruum: 39, QS. An Nisaa: 160-161, QS. Ali Imran: 130, QS. Al Baqarah: 278-279.

10 I. Markus Willy P.S.Pd, M.Dikkie Darsyah S.Pd dan Mieke Ch, 1996, Kamus Inggris Indonesia-Indonesia Inggris, Surabaya: Penerbit Arloka, 201 dan 403.

11 Sartini, Menggali Kearifan Lokal, dalam Jurnal Filsafat, Agustus 2004, Jilid 37, Nomor 2, hal. 111. 
patut secara terus-menerus dijadikan pegangan hidup. Meskipun bernilai lokal tetapi nilai yang terkandung di dalamnya dianggap sangat universal. ${ }^{12}$

Kearifan lokal dimaknai juga sebagai adat yang memiliki kearifan atau al'addah al-ma'rifah, yang dilawankan dengan al-'addah al-jahiliyyah. Kearifan adat dipahami sebagai segala sesuatu yang didasari pengetahuan dan diakui akal serta dianggap baik oleh ketentuan agama. ${ }^{13}$ Adat kebiasaan pada dasarnya teruji secara alamiah dan niscaya bernilai baik, karena kebiasaan tersebut merupakan tindakan sosial yang berulang-ulang dan mengalami penguatan (reinforcement).

Apabila suatu tindakan tidak dianggap baik oleh masyarakat maka ia tidak akan mengalami penguatan secara terus-menerus. Pergerakan secara alamiah terjadi secara sukarela karena dianggap baik atau mengandung kebaikan. Adat yang tidak baik akan hanya terjadi apabila terdapat unsur pemaksaan oleh penguasa. Bila demikian maka ia tidak tumbuh secara alamiah tetapi dipaksakan.

Banyak ungkapan dan perilaku yang bermuatan nilai luhur, penuh kearifan, muncul di komunitas lokal sebagai upaya dalam menyikapi permasalahan di semua aspek kehidupan termasuk ekonomi, yang dialami oleh masyarakat tersebut.

Realita ini muncul ke permukaan karena tidak adanya solusi global yang dapat membantu memberikan jawaban terhadap segala kejadian yang ada di sekitar lingkungan tempat tinggal mereka. Ketentuan umum yang selama ini menjadi standar bersama sudah tidak lagi menjangkau permasalahan yang mengemuka di komunitas lokal. Masyarakat yang menghuni di suatu tempat tertentu sudah dapat menyelesaikan permasalahannya dengan solusi yang penuh kearifan tanpa harus memakai standar yang berlaku secara umum.

Di sisi lain, komunitas lokal (local community) menjawab tantangan kehidupan ini dengan kearifan dan kebijaksanaan yang dimilikinya. Kearifan atau kebijaksanaan (wisdom) tersebut muncul bisa jadi karena pengalaman yang selama ini terjadi telah menjadikannya sebagai jawaban dan solusi terhadap masalah yang sedang dihadapinya. Faktor ke-terlibatan para pendahulu, nenek moyang, yang mewariskan tradisi tersebut kepada generasi berikutnya menjadi sangat penting bagi terjaganya kearifan tersebut.

Dalam perkembangannya, bisa jadi kearifan yang timbul antar komunitas lokal itu berbeda dengan yang lainnya, tanpa menghilangkan substansi yang dimiliki dari nilai kearifan tersebut, yaitu berfungsi sebagai solusi terhadap masalah yang

12 I Ketut Gobyah "Berpijak pada Kearifan Lokal” dalam http://www. balipos.co.id, diakses pada $17 / 9 / 2003$.

13 Sartini, “Menggali...”, hal. 112. Lihat juga “Penjelasan Tentang 'Urf” dalam Pikiran Rakyat terbitan 6 Maret 2003. 
ada di sekitarnya. Sehingga, dalam beberapa hal akan memungkinkan timbulnya kearifan yang beranekaragam dari komunitas lokal tersebut, walau dengan obyek permasalahan yang sama.

Kearifan lokal dalam perspektif hukum ekonomi Islam adalah 'urf. Secara etimologi 'urf berarti baik, kebiasaan dan sesuatu yang dikenal. 'Urf sering diartikan dengan segala sesuatu yang sudah saling dikenal di antara manusia yang telah menjadi kebiasaan atau tradisi, baik bersifat perkataan, perbuatan atau dalam kaitannya dengan meninggalkan perbuatan tertentu. ${ }^{14}{ }^{\prime} U r f$ tidak terjadi pada individu tetapi merupakan kebiasaan orang banyak atau kebiasaan mayoritas suatu kaum dalam perkataan atau perbuatan. 'Urf bukan kebiasaan alami, tetapi muncul dari praktik mayoritas umat yang telah mentradisi. ${ }^{15}$

Para ulama membagi 'urf menjadi dua, yaitu 'urf shahih dan 'urf fasid. 'Urf shahih adalah 'urfyang tidak bertentangan dengan Al-Quran dan Al-Hadis, yang sifatnya tidak menghalalkan yang haram dan mengharamkan yang halal. ${ }^{16}$ Misalnya saling pengertian manusia atau kebiasaan manusia mengenai transaksi jual-beli secara borongan, pemilik toko mengantarkan barang belian yang berat/besar, ke rumah pembeli seperti lemari, kursi, dan peralatan rumah tangga yang berat lainnya tanpa dibebani biaya tambahan, jual beli TV, radio, mobil dan barang-barang elektronik lainnya dengan garansi. Demikian pula dengan persewaan kamar mandi umum yang tidak dipersoalkan sedikit banyaknya air yang digunakan, meskipun harga sewanya sama. ${ }^{17}$

Sedangkan 'urf fasid adalah 'urf yang bertentangan dengan Al-Quran dan AlHadis serta menglalalkan yang haram dan mengharamkan yang halal. ${ }^{18}$ Sebagai contoh manusia saling mengerti untuk melakukan perbuatan negatif dalam hal utang-piutang dengan menambahkan bunga pada saat pengembalian, memb erikan suap pada saat melamar pekerjaan dan sebagainya.

Para ulama telah sepakat bahwa seorang mujtahid dan seorang hakim harus memelihara urf shahih yang ada di masyarakat dan menetapkannya sebagai hukum. Para ulama juga menyepakati bahwa 'urf fasid harus dijauhkan dari pengambilan dan

14 Muhammad Abu Zahrah, (tt),Ushul al-Fiqh, Al Qahirah: Dar al-Fikr al-Arabi, hal. 216. Lihat juga Abdul Wahhab Khallaf, 1985, Kaidah-kaidah Hukum Islam, Bandung: Risalah, hal. 132.

15 Agustianto, "Penerapan 'Urf dalam Ekonomi Islam” dikutip dari http://www.scribd.com/ doc/13148923/ushul-fiqh-bagian-10-urf-agustianto. Diakses pada tanggal 5 Agu 2010 21:00:54 GMT.

16 Abdul Wahhab Khallaf, 1985, Kaidah-kaidah Hukum Islam, Bandung: Risalah, hal. 132.

17 Ala' Eddine Kharoufa, 2000, Philosophy of Islamic Shariah and Its Contribution to the Science of Contemporary Law, Saudi Arabia: Islamic Development Bank, hal. 68.

18 Ibid., hal. 133. 
penetapan hukum..$^{19}$ Dengan demikian 'urf fasid harus dihindari karena melestarikan 'urf fasid berarti menentang hukum syara' atau membatalkan ketentuan syara'.

Dari paparan tersebut di atas dapat dipahami bahwa, 'urf shahih bisa menimbulkan sebuah hukum baru dengan berlandaskan ijtihad ulama yang berpendapat bahwa 'urf shahih tidak bertentangan dengan hukum Islam dengan kaidah fikih yang biasa disebut Al-'Adah Muhakkamah ${ }^{20}$ yaitu " adat dapat dijadikan pertimbangan dalam menetapkan hukum."

Dari pembahasan tersebut di atas dapat disimpulkan bahwa, antara kearifan lokal dan 'urf shahih mempunyai titik temu yang sangat jelas, karena kearifan lokal adalah gagasan-gagasan setempat (local) dan perilaku yang bersifat bijaksana, penuh kearifan, bernilai baik, yang tertanam dan diikuti oleh anggota masyarakatnya. Demikian pula 'urf yaitu, segala sesuatu yang sudah saling dikenal di antara manusia yang telah menjadi kebiasaan atau tradisi, baik bersifat perkataan, perbuatan atau dalam kaitannya dengan meninggalkan perbuatan tertentu.

Berpijak dari titik temu tersebut maka, perilaku ekonomi yang selama ini telah menjadi kearifan lokal dan tidak bertentangan dengan hukum dan prinsipprinsip ekonomi Islam, bisa menambah pengembangan khazanah keilmuan dalam ekonomi Islam dalam merespon perkembangan jaman.

\section{Toleransi Ekonomi Islam Terhadap Kearifan Lokal}

Ekonomi Islam di Indonesia secara riil sudah dilaksanakan dalam kehidupan masyarakat muslim pada tingkat keluarga. Bahkan komunitas muslim tertentu telah menjalankan tata cara pemenuhan kebutuhan hidupnya dengan penuh kearifan dan kebijaksanaan. Nilai-nilai wisdom (kearifan) tersebut dijadikan acuan di dalam melakukan kegiatan ekonomi. Dalam hal ini, ekonomi Islam difahami sebagai tata cara pemenuhan kebutuhan hidup yang orientasinya didasarkan pada aturan syariah Islam untuk pencapaian keridhaan Allah Swt.

Penerimaan 'urf suatu komunitas maupun daerah setempat sebagai bagian yang menyatu dari suatu sistem hukum, sepanjang tidak bertentangan dengan prinsipprinsip hukum ekonomi Islam, maka dibolehkan dalam Islam. Penetapan hukum atas fenomena ekonomi dari pengalaman suatu masyarakat atau kawasan tertentu yang lebih dikenal dengan kearifan lokal, dalan kajian ilmu ushul fiqh para ulama mendasarkan kepada kaidah Al 'Adah Muhakkamah.

19 Abdul Wahhab Khallaf, 1985, Kaidah-kaidah...hal. 133.

20 H.A.Djazuli, Kaidah-kaidah..., 2006, Cetakan ke-1, Jakarta: Kencana Prenada Media Group, hal. 9. 
Fatwa Imam Syafi'i dalam qaul qadim yang ditetapkan di Bagdad, kemudian dimodifikasi sendiri oleh beliau menjadi qaul jadid ketika diformulasikan di Mesir merupakan contoh yang cukup representatif terhadap pengakuan kearifan lokal sebagai 'urf. ${ }^{21}$ Menurut Imam Syafi'i, perbedaan tempat dapat menimbulkan perubahan hukum, meskipun kasusnya sama. Adanya kemungkinan perubahan hukum seperti ini disepakati oleh Ibn Qayyim Al Jauziyah. Dalam I’lam Al-Muwaqqi’in, ia setuju bahwa perbedaan waktu, lokasi, tradisi dan kondisi dapat menimbulkan perbedaan hukum. ${ }^{22}$

Berdasarkan fakta tersebut, Ahmad Mustafa al-Maraghi pun menyatakan bahwa suatu kebijakan hukum dapat saja berubah sesuai dengan kondisi sosial masyarakat. Apabila suatu ketentuan hukum dirasakan sudah tidak maslahat dikarenakan terjadi perubahan kondisi sosial, maka dapat diganti dengan ketetapan baru yang lebih sesuai dengan kemaslahatan dan kondisi sosial yang ada. ${ }^{23}$

Hal yang sama juga dikatakan oleh Muhammad Rasyid Ridha, bahwa suatu ketetapan hukum dapat berubah-ubah karena perubahan tempat, waktu, kondisi, dan situasi sosial masyarakat. Jika suatu ketentuan hukum tersebut tidak dibutuhkan lagi, dapat digantikan dengan ketentuan hukum baru yang sesuai dengan waktu dan situasi terakhir. ${ }^{24}$

Di Indonesia terdapat banyak kearifan lokal di bidang ekonomi yang telah diimplementasikan oleh masyarakat maupun upaya pengembangan ekonomi Islam yang bisa dilakukan oleh lembaga keuangan syari'ah. Sebagai contoh dalam praktik bagi hasil. Praktik-praktik bagi hasil dalam komunitas-komunitas adat ditentukan oleh prinsip-prinsip ekonomi yang dianut masing-masing komunitas adat.

Di komunitas lokal di pegunungan Tengger yang sudah mengalami proses "individualisasi" kepemilikan tanah selama ratusan tahun, menunjukkan bahwa sistem bagi hasil yang terjadi umumnya adalah antara keluarga pemilik tanah dengan penyewa/pemakai, walaupun biasanya memiliki hubungan kekerabatan sehingga pengaturannya relatif mengambil bentuk-bentuk yang lunak..$^{25}$

Petani yang menggarap tanah orang lain sedikitnya mendapatkan 50\% dari panenan (maro/paron), dan seringkali lebih, bahkan sampai 75\% (telon). Di dataran rendah di

21 Abdul Wahhab Khallaf, 1985, Kaidah-kaidah...hal. 133.

22 Ibn Qayyim Al Jauziyah, tt, I'lam Al-Muwaqqi’in, jilid 3, Beirut: Dar Al-Jalil, hal. 3.

23 Ahmad Mustafa al-Maraghi, tt, Tafsir al-Maraghi, Juz I, Beirut: Dar al-Fikr, hal. 187.

24 Muhammad Rasyid Ridha, tt, Tafsir al-Manar, Juz I, Bairut: Dar al-Fikr, hal. 414.

25 Abdon Nababan, "Menemukan Jalan Baru Kemandirian Ekonomi Indonesia" dalam makalah untuk pengantar diskusi terbatas Aliansi Masyarakat Adat Nusantara (AMAN) di Jakarta, 5 Juli 2009, hal. 2. Berdasarkan penelitian yang pernah dilakukan Nababan (1995) di empat propinsi yaitu kalimantan Timur, Maluku, Irian Jaya Dan Nusa Tenggara Timur. 
Jawa, pengaturan bagi hasil ini jauh lebih keras karena bukan didasarkan pada "kekerabatan", tetapi “patronase" atau "kerjasama antara dua kelas yang berbeda dalam masyarakat”. Dalam hal ini Orang Tengger di gunung memperlihatkan respon terhadap kepentingan-kepentingan yang lebih luas dari sekedar maksimalisasi pasar semata-mata. ${ }^{26}$

Bagi mereka penyewa tidak menjadi lebih tinggi statusnya dari pemilik tanah. Pemilik tanah yang menyediakan tanah kadang-kadang juga turut dalam penanaman atau saat panen (bukan kewajiban, tetapi lebih sebagai kemurahan hati). Penyewa/ penggarap bertanggung-jawab dalam penyediaan bibit dan pekerja yang diperlukan. Penyewa dan pemilik tanah sama-sama berpartisipasi dalam pengadaan pupuk. ${ }^{27}$ Di dalam konsep ekonomi Islam praktik bagi hasil seperti ini disebut sebagai bagi hasil dengan prinsip Al-Muzara'ah (Harvest-Yield Profit Sharing) ${ }^{28}$

Selain itu pada masyarakat adat manggarai terdapat berbagai aktivitas ekonomi lokal seperti: ${ }^{29}$

1. Celong adalah sistem pinjam barang/tanah atau semacam sewa kendaraan (kuda/kerbau untuk kepentingan pengolahan sawah). Pembayaran celong bisa berupa turut serta mengerjakan sawah si pemilik ternak atau kendaraan atau turut membantu mengerjakan atau dengan memberikan hasil pertanian setelah panen. Varian pembayaran atau kontraprestasinya cukup banyak. Konsep celong ini selalu bermakna bahwa, pada akhir masa celong barang akan dikembalikan dalam keadaan seperti semula. Konsep celong tersebut sama dengan ijarah yaitu akad pemindahan hak guna atas barang atau jasa, melalui pembayaran upah sewa, tanpa diikuti dengan pemindahan kepemilikan (ownership/ milkiyyah) atas barang itu sendiri. ${ }^{30}$

2. Sida adalah sistem pembagian beban ekonomi (uang atau barang), dimana saudara lelaki membagikannya secara merata kepada saudari perempuan dalam satu ayah atau satu kakek atau satu buyut atau antara anak rona dengan anak wina. Anak rona berarti adalah keluarga dari mana istri berasal berdasarkan hubungan darah sedangkan anak wina adalah keluarga suami yang mengawini

26 Ibid., hal. 3.

27 Ibid.

28 Sayyid Sabiq, 1987, Fiqhus Sunnah, vol III, Cetakan ke-8, Beirut: Darul Kitab al-'Arabi, hal. 173. Lihat juga Muhammad Rawas Qal'aji, 1985, Mu'jam Lughat al-Fuqaha, Beirut: Darun-Nafs.

${ }^{29}$ Agustinus Dawarja, "Sistem Ekonomi Adat Manggarai Nusantara”, dikutip dari http:// rayhanasadira.blogspot.com/2009/06/sistem-ekonomi-adat-manggarai-nusantara.html, diakses pada tanggal 9 Agu 2010 08:26:00 GMT.

30 Muhammad Rawas Qal'aji, 1985, Mu’jam Lughat al-fuqaha, Beirut: Darun Nafs dan Sayyid Sabiq, 1987, Fiqhus Sunnah, Cetakan ke-8, Vol III, Beirut: Darul Kitab al-Arabi, hal. 183. 
perempuan. Dalam adat manggarai, dalam diri orang selalu memiliki posisi ganda sebagai anak rona dan anak wina sekaligus. Tergantung kepada dengan siapa seseorang menyebut diri sebagai anak rona dan anak wina. Konsep seperti ini di dalam ekonomi Islam disebut sebagai sistem kepemilikan berdasarkan pembagian harta warisan. ${ }^{31}$

3. Ngende adalah suatu perbuatan ekonomi dimana orang yang mengalami kekurangan sesuatu dengan membawa barang tertentu kepada orang yang memiliki kemampuan ekonomi lebih baik dalam hubungan darah maupun hubungan perkawinan atau hubungan pada umumnya untuk dimintakan diberikan suatu barang. Sebagai contoh orang yang tidak memiliki beras lalu membawa jagung untuk dimintakan diberikan beras.

Dalam masyarakat adat jual beli dilangsungkan dengan cara saling menukarkan harta dengan harta. Cara penentuan apakah antara barang yang ditukar tersebut memiliki nilai yang sebanding tergantung kepada kebiasaan masyarakat adat tersebut. Jual beli seperti ini disebut dengan barter atau al-Muqayyadah. ${ }^{32}$

4. Cimpa adalah suatu pemberian secara cuma-cuma tanpa ada harapan akan imbalan secara langsung, namun diharapkan nanti suatu waktu si pemberi juga diberikan oleh orang yang menerima cimpaan jika ada. Cimpa bisa disamakan dengan konsep hibah ${ }^{33}$ atau pemberian cuma-cuma.

Contoh lain lagi upaya implementasi ekonomi berbasis kearifan lokal adalah, pemberdayaan lembaga koperasi. Koperasi merupakan instrumen ekonomi yang dapat menjadi sarana yang baik untuk membangun masyarakat. Sebab koperasi dapat menyentuh lapisan masyarakat menengah ke bawah, artinya masyarakat cenderung mudah untuk mengimplementasikannya dalam dunia nyata.

Selain itu, instrumen tersebut lebih tahan terhadap keadaan ekonomi apapun, karena dalam pelaksanaannya koperasi melakukan kegiatannya sesuai dengan sistem ekonomi Islam yang bertujuan pada mashlahah yang mengutamakan kepentingan bersama.

Apalagi jika dilakukan dengan konsep-konsep yang memperhatikan alam dan lingkungan sekitar. Sehingga koperasi syari’ah didirikan dan dikembangkan dengan berbasis kearifan lokal. Dengan demikian koperasi syari'ah dapat menjadi solusi yang radikal sesuai dengan permasalahan yang ada di wilayah setempat.

31 Abdul Azis Dahlan, 1997, Ensiklopedi Hukum Islam, jilid 2, Cetakan Pertama, Jakarta: PT. Intermasa, hal. 307.

32 Ibid., jilid 3, hal. 828.

33 Ibid., jilid 2, hal. 540. 
Melalui konsep kearifan lokal, koperasi syari'ah yang dibentuk nantinya akan melakukan kegiatan dan program-programnya sesuai dengan potensi alam dan lingkungan di sekitar koperasi syari'ah berada. Misalnya, sebuah koperasi syari’ah yang dibangun di daerah A, melakukan kegiatan koperasinya berupa kegiatan produksi dan pembiayaan (simpan-pinjam). Kegiatan pembiayaan (simpan-pinjam) dilakukan sebagai pendanaan bagi para anggota yang ingin melakukan kegiatan usaha (wirausaha).

Dana tersebut merupakan dana bergulir yang wajib dikembalikan dengan sistem bagi hasil yang telah disepakati oleh kedua belah pihak (koperasi syari'ah sebagai lembaga pemberi pinjaman dan anggota koperasi yang melakukan pinjaman). Koperasi syari'ah yang ada harus sudah mengarahkan calon wirausahawan baru untuk melakukan usahanya sesuai dengan potensi kekayaan alam dan lingkungan di wilayah tersebut.

Misalnya, daerah A memiliki potensi pertanian, perkebunan dan buah-buahan serta budidaya perikanan laut yang merupakan potensi dominan yang ada di daerah tersebut. Oleh karena itu wirausahawan diarahkan untuk bisa memanfaatkan potensi tersebut secara kreatif. Sebelumnya, pihak pengurus juga harus sudah melakukan kegiatan pembinaan terhadap seluruh anggotanya terkait hal-hal yang berkaitan dengan fokus kerja mereka, yaitu program-program berbasis kearifan lokal.

Selain itu, kegiatan koperasi syari'ah yang berkaitan dengan penyediaan bahan baku produksi juga harus dapat memanfaatkan kearifan lokal yang ada. Misalnya dalam penyediaan alat-alat pertanian, mesin-mesin pertanian, alat-alat perikanan, peternakan dan bahan-bahan baku produksi lainnya yang bisa mendukung pengembangan operasional koperasi berbasis kearifan lokal.

Dalam penanggulangan kemiskinanpun program-program lembaga keuangan syari'ah baik perbankan, non perbankan, maupun lembaga keuangan publik Islam, dapat bekerja sama dengan pemerintah untuk berupaya mencari alternatif kebijakan yang sesuai dengan kondisi spesifik lokal, serta menggali dan memahami kearifan penduduk lokal dalam hubungannya dengan upaya preventif menanggulangi kemiskinan.

Kemiskinan seyogyanya bersimpul pada empat konsep yang sudah dikenal selama ini, baik kemiskinan absolut dan relatif, maupun kemiskinan objektif dan subjektif. Kemiskinan absolut dan relatif adalah konsep kemiskinan yang mengacu pada kepemilikan materi dikaitkan dengan standar kelayakan hidup. Artinya merujuk pada perbedaan sosial yang diperoleh dari distribusi pendapatan. Dengan demikian 
pada kemiskinan absolut ukurannya sudah terlebih dahulu ditentukan dengan angkaangka nyata, sementara kemiskinan relatif, ditentukan berdasarkan perbandingan tingkat kesejahteraan antar penduduk.

Pendekatan objektif dan subjektif terhadap kemiskinan berkaitan erat dengan perkembangan pendekatan kualitatif-partisipatoris. ${ }^{34}$ Kebutuhan kalori adalah pendekatan objektif, sedangkan kemiskinan subjektif lebih menekankan pemahaman pada konsep kemiskinan dari sudut pandang masyarakat miskin. Dengan menggali dan mengembangkan kearifan lokal, kemiskinan tidak hanya dapat dikurangi (relieving) tetapi juga dapat dihindari (preventing) karena lestarinya sumberdaya bagi generasi berikutnya. ${ }^{35}$

Kearifan lokal mengandung norma dan nilai-nilai sosial yang mengatur bagaimana seharusnya membangun keseimbangan antara daya dukung lingkungan alam dengan gaya hidup dan kebutuhan manusia. Oleh karena itu, kearifan lokal seharusnya menjadi bagian yang tidak terpisahkan dari kebijakan anti kemiskinan.

Di luar pendekatan yang bercorak strukturalis, sesungguhnya dapat digali mozaik kehidupan masyarakat setempat yang bernama kearifan kolektif atau kearifan budaya. Di setiap masyarakat manapun kearifan tersebut tertanam dalam di relung sistem pengetahuan kolektif mereka yang dialami bersama. Itulah yang sering disebut sebagai kearifan lokal (local-wisdom). Pela-gandong di Maluku misalnya, merupakan contoh dari kearifan budaya lokal, atau konsep gotong royong yang selalu dilakukan oleh masyarakat pedesaan di pulau jawa.

Masih banyak contoh kearifan lokal di bidang ekonomi yang bisa dieksplorasi dalam upaya pengembangan keilmuan dan praktik ekonomi Islam di Indonesia. Kearifan lokal sama sekali tidak bisa diperoleh melalui suatu pendidikan formal dan informal tetapi hanya bisa dipahami dari suatu pengalaman yang panjang melalui suatu pengamatan langsung. Kearifan lokal lahir dari learning by experience yang tetap dipertahankan dan diturunkan dari generasi ke generasi.

Kegunaan utama kearifan lokal adalah menciptakan keteraturan dan keseimbangan antara kehidupan sosial, budaya dan kelestarian sumberdaya alam. Pada ranah inilah ekonomi Islam dapat bersinergi dalam upaya merespon

34 Marcus J. Pattinama, "Pengentasan Kemiskinan Dengan Kearifan Lokal (Studi Kasus di Pulau Buru-Maluku dan Surade-Jawa Barat)” dalam MAKARA Jurnal Sosial Humaniora, Vol. 13, No. 1, Juli 2009, hal. 1-12.

35 Soerjani, M. 2005. “Krisis Kearifan Kita”. Dalam Kompas, Kamis 20 Oktober 2005. 
perkembangan masyarakat terkait dengan aspek ekonomi. Upaya toleransi ekonomi Islam terhadap kearifan lokal tersebutlah, yang menjadikan perkembangan umat Islam begitu dinamis dan dialektis dalam catatan sejarah di masa kini maupun masa yang akan datang.

\section{E. Penutup}

Dari paparan tersebut di atas dapat diambil kesimpulan bahwa, setiap aktivitas ekonomi harus berlandaskan kepada sumber-sumber hukum ekonomi Islam dan tidak boleh bertentangan dengan prinsip-prinsip ekonomi Islam dalam berijtihad atas suatu fenomena ekonomi. Dalam ekonomi Islam, terdapat prinsip-prinsip yang harus dipenuhi apabila sebuah interaksi antar sesama manusia akan dilakukan. Prinsip-prinsip ini harus dijadikan sebagai aturan dalam melakukan aktivitas ekonomi.

Di antara sumber-sumber hukum ekonomi Islam seperti Al Qur'an, Sunnah, Ijma', Fatwa Sahabat Nabi, Qiyas, Istihsan, 'Urf, Mashalih Mursalah, Sadd adzdzara'i, Istishhab dan Syar'u man qablana, maka 'Urf adalah sumber hukum ekonomi Islam yang dapat dijadikan sebagai dasar untuk mencari titik temu antara aktivitas ekonomi yang merupakan kearifan lokal dengan ekonomi Islam. Dengan demikian dapat dijustifikasi, apakah kearifan lokal bidang ekonomi tersebut relevan dengan hukum dan prinsip-prinsip ekonomi Islam.

Antara kearifan lokal dan 'urf shahih mempunyai titik temu yang sangat jelas, karena kearifan lokal adalah gagasan-gagasan setempat (local) dan perilaku yang bersifat bijaksana, penuh kearifan, bernilai baik, yang tertanam dan diikuti oleh anggota masyarakatnya. Demikian pula 'urf yaitu, segala sesuatu yang sudah saling dikenal di antara manusia yang telah menjadi kebiasaan atau tradisi, baik bersifat perkataan, perbuatan atau dalam kaitannya dengan meninggalkan perbuatan tertentu.

Dengan demikian, perkembangan umat Islam yang begitu dinamis dan dialektis hanya dapat terwujud jika toleransi ekonomi Islam terhadap kearifan lokal dapat diupayakan sehingga tercipta sinergi di antara keduanya.

\section{DAFTAR PUSTAKA}

Abdul Azis Dahlan. 1996. Ensiklopedi Hukum Islam, Jakarta: PT. Ichtiar Baru Van Hoeve. 
Abdon Nababan. "Menemukan Jalan Baru Kemandirian Ekonomi Indonesia” dalam makalah untuk pengantar diskusi terbatas Aliansi Masyarakat Adat Nusantara (AMAN) di Jakarta. 5 Juli 2009.

Agustinus Dawarja. "Sistem Ekonomi Adat Manggarai Nusantara”, dikutip dari http://rayhanasadira.blogspot.com/2009/06/sistem-ekonomi-adatmanggarai-nusantara.html. diakses pada tanggal 9 Agu 2010 08:26:00 GMT.

Ahmad Mustafa al-Maraghi, tt, Tafsir al-Maraghi, Juz I, Beirut: Dar al-Fikr.

Ala' Eddine Kharoufa. 2000. Philosophy of Islamic Shariah and Its Contribution to the Science of Contemporary Law, Saudi Arabia: Islamic Development Bank.

Agustianto, "Penerapan 'Urf dalam Ekonomi Islam” dikutip dari http://www.scribd. com/doc/13148923/ushul-fiqh-bagian-10-urf-agustianto. Diakses pada tanggal 5 Agu 2010 21:00:54 GMT.

Abdul Wahhab Khallaf.1985. Kaidah-kaidah Hukum Islam, Bandung: Risalah. Ahmad al-Nadwi. 1998. al-Qawa'id al-Fiqhiyah. Cetakan ke-V. Beirut: Dar al-Qalam. Ahmad Azhar Basyir. 1983. Hukum Adat Bagi Umat Islam. Cetakan Pertama. Yogyakarta: Nur Cahaya.

Frank E.Vogel dan Samuel L. Hayes, III. 2007. Hukum Keuangan Islam, Cetakan ke-1. Bandung: Penerbit Nusamedia.

H.A.Djazuli. 2006. Kaidah-kaidah Fikih, Cetakan ke-1. Jakarta: Kencana Prenada Media Group.

Ibn Qayyim Al Jauziyah, tt, I'lam Al-Muwaqqi'in, jilid 3, Beirut: Dar Al-Jalil.

I. Markus Willy P.S.Pd, M.Dikkie Darsyah S.Pd dan Mieke Ch. 1996. Kamus Inggris Indonesia-Indonesia Inggris, Surabaya: Penerbit Arloka.

I Ketut Gobyah “Berpijak pada Kearifan Lokal” dalam http://www. balipos.co.id, diakses pada 17/9/2003.

Marcus J. Pattinama. "Pengentasan Kemiskinan Dengan Kearifan Lokal (Studi Kasus di Pulau Buru-Maluku dan Surade-Jawa Barat)” dalam MAKARA Jurnal Sosial Humaniora. Vol. 13. No. 1. Juli 2009.

Muhammad Rasyid Ridha. (tt).Tafsir al-Manar, Juz I, Bairut: Dar al-Fikr.

Muhammad Abu Zahrah. (tt). Ushul al-Fiqh, Al Qahirah: Dar al-Fikr al-Arabi. 
Muhammad Rawas Qal'aji, 1985, Mu'jam Lughat al-Fuqaha, Beirut: Darun- Nafs.

Sartini, Menggali Kearifan Lokal, dalam Jurnal Filsafat, Agustus 2004, Jilid 37, Nomor 2.

Sayyid Sabiq. 1987. Fiqhus Sunnah, vol III, Cetakan ke-8, Beirut: Darul Kitab al-'Arabi. Soerjani, M. 2005. “Krisis Kearifan Kita”. Dalam Kompas. Kamis 20 Oktober 2005. Tim Penulis FSEI. 2008. Filsafat Ekonomi Islam. Cetakan Pertama. Yogyakarta: FSEI PPs UIN Sunan Kalijaga.

TON. 2010. Pengembangan Keilmuan Baru Ekonomi Islam, dalam Sharing, Majalah Ekonomi dan Bisnis Syariah, Edisi 43 Tahun IV Juli 2010. 